\title{
QbD BASED CONTROL STRATEGY OF LORATADINE NANOSUSPENSIONS AND DRY NANOPARTICLES STABILIZED BY SOLUPLUS ${ }^{\circledR}$
}

\author{
AREEN ALSHWEIAT, RITA AMBRUS *, GÁBOR KATONA, ILDIKÓ CSÓKA \\ Faculty of Pharmacy, Interdisciplinary Excellence Centre, Institute of Pharmaceutical Technology and Regulatory Affairs, \\ University of Szeged, Szeged, Hungary
}

*corresponding author: arita@pharm.u-szeged.hu

Manuscript received: January 2019

\begin{abstract}
The preparation of nanosuspensions has been introduced as a well-defined method to enhance the solubility and dissolution of poorly water-soluble drugs. The aim of this study was to evaluate the feasibility of using Soluplus ${ }^{\circledR}$ as a stabilizer for loratadine nanosuspensions. The concept of Quality by design (QbD) was followed particularly to link the critical material parameters (CMPs) and the critical process parameters (CPPs) with the required critical quality attributes (CQAs) and risk assessment (RA) to select the optimized critical material and process parameters. The ultrasonic-assisted precipitation method was selected to prepare the nanosuspensions with different concentrations of Soluplus ${ }^{\circledR}$. Particle size, polydispersity index (PDI), solubility and dissolution were set as the main CQAs. Soluplus ${ }^{\circledR}$ successfully produced loratadine nanosuspensions with particle size ranging between $168.3-245.35 \mathrm{~nm}$ and PDI in the range of 0.12 and 0.25 . The freeze dried sample with $0.6 \%$ Soluplus ${ }^{\circledR}$ (DLNS3) showed an amorphous status of loratadine with particle size and PDI in the range of $220 \pm 6.23$ and $0.21 \pm 0.02$, respectively. Contact angles, surface free energy, and polarity measurements showed an enhancement of the hydrophilic properties of DLNS3. DLNS3 displayed 121-fold saturation solubility and released approximately 57\% of loratadine within $15 \mathrm{~min}$. The effects of CMPs and CPPs on the CQA were expected by the QbD approach.
\end{abstract}

\section{Rezumat}

Prepararea nanosuspensiilor a fost introdusă ca o metodă bine definită pentru a crește solubilitatea și dizolvarea medicamentelor greu solubile în apă. Scopul acestui studiu a fost de a evalua posibilitatea utilizării Soluplus ${ }^{\circledR}$ ca stabilizator pentru nanosuspensiile cu loratadină. Conceptul de calitate prin design $(\mathrm{QbD})$ a fost urmărit în special pentru a lega parametrii critici ai materialelor (CMP) și parametrii critici ai procesului (CPP) cu atributele critice de calitate (CQA) şi evaluarea riscurilor (RA) necesare pentru a selecta materialul critic optimizat și parametrii procesului. Metoda de precipitare asistată cu ultrasunete a fost aleasă pentru a prepara nanosuspensiile cu diferite concentrații de Soluplus ${ }^{\circledR}$. Dimensiunea particulelor, indicele de polidispersie (PDI), solubilitatea și gradul de dizolvare au fost stabilite ca principale CQA. Soluplus ${ }^{\mathbb{B}}$ a condus cu succes la obținerea de nanosuspensii de loratadină cu o dimensiune a particulelor cuprinse între 168,3 - 245,35 nm și PDI în intervalul de 0,12 și 0,25 . Proba liofilizată cu $0,6 \%$ Soluplus ${ }^{\circledR}$ (DLNS3) a fost caracterizată de o stare amorfă a loratadinei cu dimensiunea particulei și PDI în domeniul $220 \pm 6,23$ şi, respectiv, $0,21 \pm 0,02$. Unghiurile de contact, energia de suprafață şi determinarea polaritătii au arătat o îmbunătăţire a proprietăţilor hidrofile ale DLNS3. Acesta a prezentat o solubilitate de saturație de 121 de ori mai mare şi a eliberat aproximativ 57\% din loratadină în decurs de 15 minute. Efectele CMP și CPP asupra CQA erau dezirabile în contextul metodei QbD.

Keywords: Loratadine nanosuspension, quality-by-design, risk assessment, precipitation

\section{Introduction}

Recently, particle size reduction to the submicron level has been proved as one of the most efficient methods to enhance solubility and dissolution, hence the bioavailability of poorly water-soluble drugs. Nanosuspension (NS) is an essential part of nanotechnology that produces particles at the submicron level stabilized by a suitable type and amount of stabilizer(s). Generally, two methods can be applied for producing NS; the top-down and the bottom-up method with the possibility of combining both methods. On the contrary to the top-down, the bottom-up method is based on building up the particles from the molecular state of the drug $[1,2]$.

Precipitation assisted by ultrasonication is a commonly used as bottom-up method. The preparation of NS is usually followed by drying procedures, such as spray drying and freeze drying, to ensure long-term stability. All the parameters related to these processes could have significant effects on the properties of NS, such as particle size, particle size distribution, and stability in addition to the properties of the dry particles, such as re-dispersibility, particle size, solubility, etc. [3-6]. 
FARMACIA, 2019, Vol. 67, 4

Loratadine (LOR), a second-generation histamine $\mathrm{H}_{1}$ receptor antagonist, is the most frequently prescribed antihistamine drug for the treatment of allergic conditions. LOR belongs to class II of the biopharmaceutical classification system and has a $\mathrm{pH}$-dependent solubility; as a consequence, it shows low and variable bioavailability. Many techniques have been adopted to enhance the solubility and dissolution of LOR, including solid dispersion, inclusion with ß-cyclodextrin derivatives, and micellar solubilisation [7-11]. On the other hand, various drug delivery systems such as microparticulated and nanoparticulated systems have been introduced to overcome the inconvenience of the currently used systems [12].

In a multivariate production process, all the parameters of the different operations should be cautiously selected and their effects on the final product must be assessed. In the case of preparing nanosuspension by precipitation ultrasonication, all the parameters related to these processes must be evaluated in addition to the drying procedure. The Quality by Design (QbD) approach supports the development of products with a predefined quality based on knowledge and risk assessment (RA). For QbD-based development, it is necessary to identify the critical quality attributes (CQAs) which critically influence the predefined quality target product profile (QTPP). Moreover, the critical material and critical process parameters (CMPs and CPPs, respectively) with high impacts on CQAs must be defined [13, 14]. In practice, the identification of CQAs, CMPs and CPPs is based on the previous practice, and literature knowledge and experience. In a recent study of our team, we evaluated the preparation of loratadine (LOR) nanosuspension by the precipitation ultrasonication method, with the use of the most commonly applied stabilizers, including polymers (hydroxylpropylmethylcellulose (HPMC), polyvinylpyrrolidone (PVP-K25)), non-ionic surfactant (Tween 80, Pluronic F68) and ionic surfactant (sodium lauryl sulphate (SLS)) as single or combined stabilizers. In the present paper, the authors emphasize the impacts of CMPs, CPPs and the effect of using a new material as a stabilizer, e.g. Soluplus ${ }^{\circledR}$, on the production of NS for loratadine. The aim was to demonstrate the efficiency of applying the QbD concept in reducing the experimental trials and predicting the results based on previously determined the CMPs and CPPs. Moreover, this study aimed to explore further possibilities for LNS stabilization with Soluplus ${ }^{\circledR}$ and evaluate its effect on the CQAs of LNS and DLNS.

\section{Materials and Methods}

\section{Materials}

Loratadine was purchased from Teva Ltd. (Budapest, Hungary). Soluplus ${ }^{\circledR}$ was purchased from BASF (Ludwigshafen, Germany). Ethanol was supplied by Spectrum-3D (Debrecen, Hungary) and trehalose dihydrate was supplied by Sigma-Aldrich (New York, USA). Water was purified by double distillation. Methods

Determination of QbD elements (CQAs, CPPs and RA) Based on prior knowledge, previous studies, preliminary experiments, and data from relevant literature, CQAs, CPPs were determined for producing LNS. Previous studies led to the selection of particle size, polydispersity, and zeta potential as CQAs. In the case of DLNS, particle size, polydispersity index, solubility, and dissolution properties were determined as CQAs. The RA was performed with Lean QbD Software ${ }^{\circledR}$ (2014QbD Works LLC., Fremont, USA). According to this software, the connections between CQAs, CMPs and CPPs were evaluated and rated on a threelevel scale. This scale reflects the impact of their interaction on the product as high $(\mathrm{H})$, medium $(\mathrm{M})$ or low (L). Further, Pareto charts were generated by the software, presenting the numeric data and the ranking of CQAs, CMPs and CPPs.

Preparation of loratadine nanosuspension and dried nanoparticles

LNSs were prepared with the precipitation-ultrasonication method. LOR was dissolved in ethanol, while Soluplus ${ }^{\circledR}$ was dissolved in water. Both solutions were filtered through a $0.45 \mu \mathrm{m}$ filter (FilterBio PES Syringe Filter, Labex Ltd., Budapest, Hungary). Afterwards, the drug solution was rapidly introduced into pre-cooled antisolvent under sonication using a UP 200s Ultrasonic processor (HielscheruUltrasonics $\mathrm{GmbH}$, Germany) for $30 \mathrm{~min}$ at $4^{\circ} \mathrm{C}$ and $50 \%$ amplitude. The temperature of sonication was controlled by JulaboF32 (JULABO GmbH, Germany). LNSs were stirred at room temperature for $24 \mathrm{~h}$ to remove the organic solvent. The selected LNS sample was lyophilized with $5 \%(\mathrm{w} / \mathrm{v})$ trehalose to produce DLNs by using a ScanVac, CoolSafe ${ }^{\mathrm{TM}}$ freeze-dryer (Labo Gene, Denmark). The selected LNS was lyophilized at $-40^{\circ} \mathrm{C}$. The solvent was sublimed under a pressure of $0.01 \mathrm{mbar}$ for $36 \mathrm{~h}$.

\section{Preparation of physical mixtures}

Physical mixtures (PMs) corresponding to the composition of LNS were prepared by blending LOR and Soluplus ${ }^{\circledR}$ in a Turbula mixer (Turbula System Schatz; Willy A. Bachofen AG Maschinenfabrik, Basel, Switzerland) using $60 \mathrm{rpm}$ for 10 minutes with a LOR:Soluplus ${ }^{\circledR}$ ratio of 1:2.4, w/w (PM1). Moreover, PM with trehalose was prepared to figure out the effect of the cryoprotectant $(\mathrm{PM} 2)$ with a LOR:Soluplus ${ }^{\circledR}$ :trehalose ratio of $1: 2.4: 20, \mathrm{w} / \mathrm{w}$.

\section{Particle size characterization}

The MPS, PDI, and ZP of LNSs were measured by dynamic light scattering using Malvern Nano ZS zetasizer (Malvern Instrument, UK), with water used as dispersant and refractive index set to 1.62. The samples were adequately diluted with distilled water and measured at $25^{\circ} \mathrm{C}$ and $\mathrm{pH}$ 5.77. 12 parallel measurements were carried out. 
Characterization of dried nanoparticles

Scanning electron microscopy (SEM). The morphology of the powder particles was investigated by scanning electron microscopy (SEM) (Hitachi S4700, Hitachi Scientific Ltd., Tokyo, Japan) at $10 \mathrm{kV}$. The samples were coated with gold-palladium ( 90 seconds) with a sputter coater (Bio-Rad SC 502, VG Microtech, Uckfield, UK) using an electric potential of $2.0 \mathrm{kV}$ at $10 \mathrm{~mA}$ for $10 \mathrm{~min}$. The air pressure was $1.3-13.0 \mathrm{mPa}$. $X$-ray powder diffraction (XRPD). The structure of lyophilized nanoparticles and raw materials was characterized using a BRUKER D8 Advance X-ray powder diffractometer (Bruker AXS GmbH, Karlsruhe, Germany) with $\mathrm{Cu} K \lambda_{\mathrm{I}}$ radiation $(\lambda=1.5406 \AA)$ and a VANTEC-1 detector. The powder samples were scanned at $40 \mathrm{kV}$ and $40 \mathrm{~mA}$, with an angular range of $3^{\circ}$ to $40^{\circ} 2 \theta$, at a step time of $0.1 \mathrm{~s}$ and a step size of $0.01^{\circ}$.

Differential scanning calorimetry (DSC). The thermal analysis was carried out using a differential scanning calorimeter (Mettler Toledo DSC $821^{\mathrm{e}}$, Mettler Inc., Schwerzenbach, Switzerland). About 3 - $5 \mathrm{mg}$ of powder was accurately weighed into DSC sample pans, which were hermetically sealed and lid pierced. An empty pan was used as a reference in an inert atmosphere under constant argon purge. The samples were examined in the temperature interval of $25^{\circ} \mathrm{C}$ $300^{\circ} \mathrm{C}$ at a heating rate of $5^{\circ} \mathrm{C} / \mathrm{min}$.

Surface free energy and polarity investigation. The contact angle, surface free energy (SFE) and polarity of the samples were measured. $0.15 \mathrm{~g}$ of sample was pressed at 1-ton hydraulic press to pastille (Perkin Elmer Hydraulic Press; PerkinElmer Inc., Waltham, MA, USA). Then, the surface of the pastilles was dripped with polar and non-polar solvents. The contact angle was detected for 30 seconds with DataPhysics OCA 20 device (DataPhysics Inc. GmbH, Filderstadt,
Germany), and then $\mathrm{Wu}$ correlation was used. The solvents were distilled water $(\gamma \mathrm{p}=50.2 \mathrm{mN} / \mathrm{m}, \gamma \mathrm{d}=$ $22.6 \mathrm{mN} / \mathrm{m})$ and diiodomethane $(\gamma \mathrm{p}=1.8 \mathrm{mN} / \mathrm{m}, \gamma \mathrm{d}=$ $49 \mathrm{mN} / \mathrm{m}$ ).

Dissolution studies

The dissolution tests were performed using the modified paddle method (USP dissolution apparatus, type II Pharma Test, Hainburg, Germany). Samples were tested in $100 \mathrm{~mL}$ of PBS ( $\mathrm{pH} 7.4)$. The paddles were rotated at $100 \mathrm{rpm}$ at $37^{\circ} \mathrm{C}$. At a predetermined time, $5 \mathrm{~mL}$ aliquots were withdrawn and filtered. The concentration of LOR was measured spectrophotometrically (Unicam UV/VIS Spectrophotometer, Cambridge, UK) at $\chi_{\max } 248 \mathrm{~nm}$.

\section{Results and Discussion}

Knowledge space development for the precipitation ultrasonication method

The development of knowledge space could visualize the overall manufacturing process with respect to the selection of CPPs, and the definition of the required CQAs [13].

Table I

Required CQAs for LNS and dry nanoparticles

\begin{tabular}{lc}
\hline \multicolumn{1}{c}{ Parameter } & Value \\
\hline Mean particle size $(\mathrm{nm})$ & $100-300$ \\
Polydispersity index & $0.1-0.3$ \\
Solubility $(\mu \mathrm{g} / \mathrm{mL})$ & $>25$ \\
Released drug after 30 $\mathrm{min}(\%)$ & $50 \%-85 \%$ \\
\hline
\end{tabular}

To adapt to QbD-based development principles, the first step was to define the required CQAs (Table I), followed by the identification of the CPPs and affects the CQAs considering particle size the main factor based on the definition of nanosuspension and on its consequences on the other CQAs, such as solubility and dissolution (Table II).

Table II

The effects of different material and process parameters on quality of attributes for the precipitation ultrasonication method

\begin{tabular}{|c|c|}
\hline Parar & Justification \\
\hline $\begin{array}{l}\text { Prug amount in the } \\
\text { olvent phase }\end{array}$ & $\begin{array}{l}\text { An increase in drug concentration decreases particle size due to increased saturation. This effect lasts } \\
\text { until the optimum concentration above which particle size increases as drug concentration increases. }\end{array}$ \\
\hline Stabilizer type & $\begin{array}{r}\text { The proper type depends mainly on the affinity between the drug particles and the specific part of the } \\
\text { stabilizer. }\end{array}$ \\
\hline 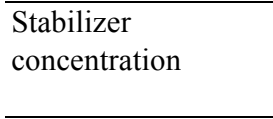 & $\begin{array}{r}\text { A sufficient amount is required to cover the nascent surface to prevent aggregation and agglomeration. } \\
\text { However, a high concentration may form a viscous solution that can reduce solvent diffusion and } \\
\text { affect ultrasonic waves transmission. }\end{array}$ \\
\hline $\begin{array}{l}\text { olvent: antisolve } \\
\text { titio }\end{array}$ & $\begin{array}{l}\text { Particle size decreases by decreasing the solvent: antisolven } \\
\text { supersaturation. This reduction in particle size comes to }\end{array}$ \\
\hline $\begin{array}{l}\text { Antisolvent } \\
\text { emperature }\end{array}$ & rows particle size distribution. \\
\hline Sonication & $\begin{array}{l}\text { Particle size usually increases with the increase of ultrasonic power input due to the increased erosion } \\
\text { effect on the surface of large crystals and crystal agglomerates. However, if the energy exceeds a } \\
\text { critical value, it increases the kinetic energy of particles and increases agglomeration. }\end{array}$ \\
\hline onication & The optimal time length can support particle size reduction, the time effect is linked to the sonication power. \\
\hline reeze d & are \\
\hline
\end{tabular}




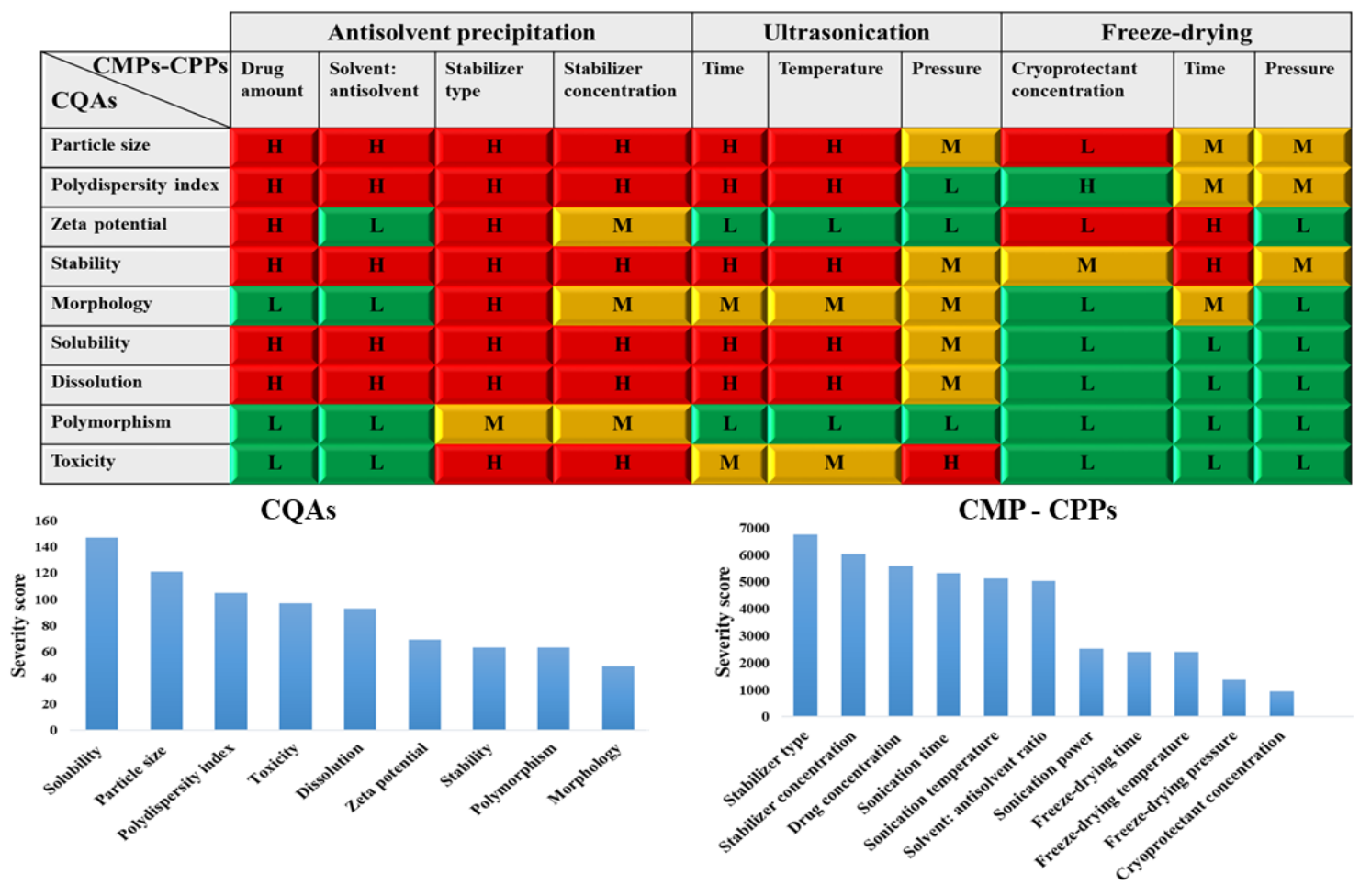

Figure 1.

Results of RA-based relationships between CQAs and CPPs (upper part) and the Pareto charts of the CQAs and CPPs with calculated numeric severity scores (lower part)

Afterwards, the RA relation-ships between CQAs and CPPs in addition to the numeric data of the critical factors and their ranking (Pareto charts) were determined (Figure 1) to finally select the optimized CMPs and CPPs that support the achievement of the required CQAs.

Table III shows the optimized CMPs and CPPs based on our previous studies [13].

Table III

Critical process parameters for the preparation of LNS and dry nanoparticles

\begin{tabular}{lc}
\hline \multicolumn{1}{c}{ Parameter } & value \\
\hline Solvent: antisolvent & $1: 40$ \\
Sonication time (min) & 30 \\
Sonication temperature $\left({ }^{\circ} \mathrm{C}\right)$ & 4 \\
Sonication amplitude $(\%)$ & 50 \\
Cryoprotectant concentration $(5 \% \mathrm{w} / \mathrm{v})$ & 5 \\
Freezing time $(\mathrm{h})$ & 24 \\
\hline
\end{tabular}

Preparation of nanosuspensions and dry nanoparticles

MPS, PDI and ZP results are summarized in Table IV. The freshly prepared LNSs showed a significant reduction in MPS at the range of 168.3 and 245.35 $\mathrm{nm}$ monodispersion with low PDI index. Soluplus ${ }^{\circledR}$ produced LNS with the lowest particle size compared to the commonly used stabilizers [14]. Soluplus ${ }^{\circledR}$ is an amphiphilic compound that interacted with the nonpolar surface area of LOR and covered the newly formed surfaces, providing steric hindrance to prevent recrystallization from the solution and aggregation of the primary particles. Higher concentrations of Soluplus ${ }^{\circledR}$ could stabilize the NS more effectively due to weak Ostwald ripening as the drug will diffuse slowly from the formed micelles [15].

The MPS of the three samples were preserved within the nanorange (Table V). LNS3 with the smallest MPS was selected for further characterization as dry nanoparticles (DLNS3).

Table IV

MPS, PSD and ZP of pure LOR and LNSs

\begin{tabular}{|c|c|c|c|c|c|}
\hline Sample & Drug amount (mg) & Soluplus ${ }^{(B)}$ conc. $(\% \mathrm{w} / \mathrm{v})$ & MPS (nm) & PDI & $\mathrm{ZP}(\mathrm{mV})$ \\
\hline LOR & 100 & - & $4607.5 \pm 41.7$ & $0.71 \pm 0.18$ & $-7.73 \pm 5.28$ \\
\hline LNS1 & 100 & 0.2 & $220.35 \pm 5.3$ & $0.25 \pm 0.0$ & $-21.5 \pm 5.59$ \\
\hline LNS2 & 100 & 0.4 & $178.7 \pm 6.5$ & $0.12 \pm 0.02$ & $-19.7 \pm 4.85$ \\
\hline LNS3 & 100 & 0.6 & $168.3 \pm 6.5$ & $0.16 \pm 0.03$ & $-16.5 \pm 6.59$ \\
\hline
\end{tabular}


Table V

MPS, PDI and ZP for LNSs on the first 3 days of preparation

\begin{tabular}{|c|c|c|c|c|c|c|c|c|c|}
\hline Sample & \multicolumn{3}{|c|}{ LNS1 } & \multicolumn{3}{c|}{ LNS2 } & \multicolumn{3}{c|}{ LNS3 } \\
\hline Day & MPS (nm) & PDI & ZP (mV) & MPS (nm) & PDI & ZP (mV) & MPS (nm) & PDI & ZP (mV) \\
\hline $\mathbf{1}$ & $212.1 \pm 0.9$ & $0.12 \pm 0.01$ & $-26.8 \pm 0.07$ & $171.7 \pm 1.9$ & $0.016 \pm 0.0$ & $-22.6 \pm 2.5$ & $158.1 \pm 6.2$ & $0.22 \pm 0.17$ & $-22.4 \pm 2.1$ \\
\hline $\mathbf{2}$ & $196.8 \pm 0.1$ & $0.15 \pm 0.02$ & $-25.5 \pm 6.6$ & $168.2 \pm 11.3$ & $0.017 \pm 0.02$ & $-24.6 \pm 0.8$ & $149.2 \pm 7.4$ & $0.19 \pm 0.01$ & $-19.1 \pm 2.3$ \\
\hline $\mathbf{3}$ & $217.15 \pm 9.5$ & $0.17 \pm 0.05$ & $-22.5 \pm 2.5$ & $178.6 \pm 3.6$ & $0.015 \pm 0.0$ & $-20.2 \pm 3.5$ & $158.5 \pm 6.7$ & $0.17 \pm 0.09$ & $-18 \pm 1.4$ \\
\hline
\end{tabular}

DLNS3 showed a MPS in the order of $220 \pm 6.23 \mathrm{~nm}$, PDI range $0.21 \pm 0.02$ and $\mathrm{ZP}$ of $-23.8 \pm 4.4 \mathrm{mV}$ after constitution in $5 \mathrm{~mL}$ of distilled water.

Morphology

SEM images (Figure 2) showed that LOR had an irregular rod-like crystal shape with a particle size above $5 \mu \mathrm{m}$ and some aggregation emphasized the broad distribution of the raw drug. DLNS3 had spherical particles at the nanosized scale embedded within the carriers. The effect of stabilizer type on morphology was expected and confirmed here as Soluplus ${ }^{\circledR}$ produced a spherical shape, while F68 and F68 with PVP-K25 produced short rod morphologies [14].

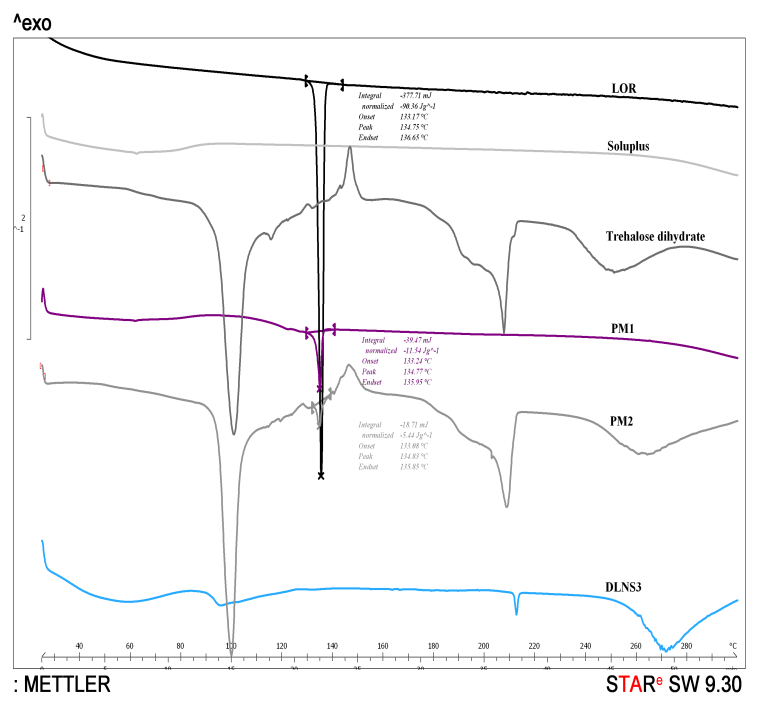

Figure 3.

DSC thermogram of LOR, Soluplus ${ }^{\circledR}$, trehalose dihydrate, PM and DLNS3

\section{Structural analysis (DSC and XRPD)}

The thermal behaviours of the pure materials and DLNS3 are shown in Figure 3. LOR showed a single narrow peak at $134.7^{\circ} \mathrm{C}$ corresponding to its melting point. The Soluplus ${ }^{\circledR}$ thermogram showed a wide peak, which represents water evaporation. PMs showed the crystalline state of LOR, while the absence of a LOR peak in DLNS3 indicates the presence of LOR in an amorphous state. Figure 4 shows the XRPD spectra of raw materials, PMs and DLNS3. The characteristic crystalline peaks disappeared in the pattern of the dry DLNS3. This revealed the presence of LOR in its amorphous state.

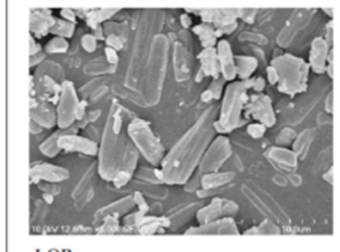

LOR

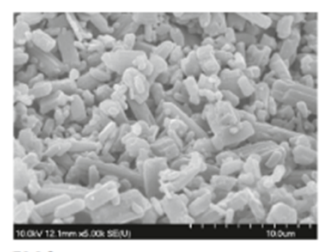

PM 2

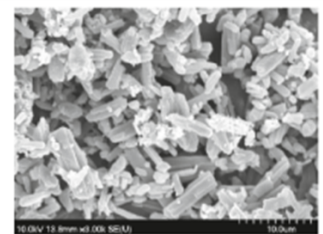

PM 1

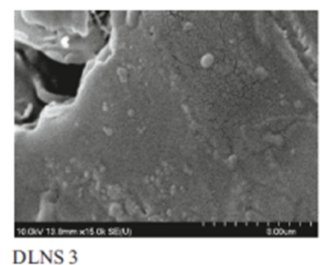

DLNS 3
Figure 2.

SEM image of LOR, Soluplus ${ }^{\circledR}$, PMs and DLNS3

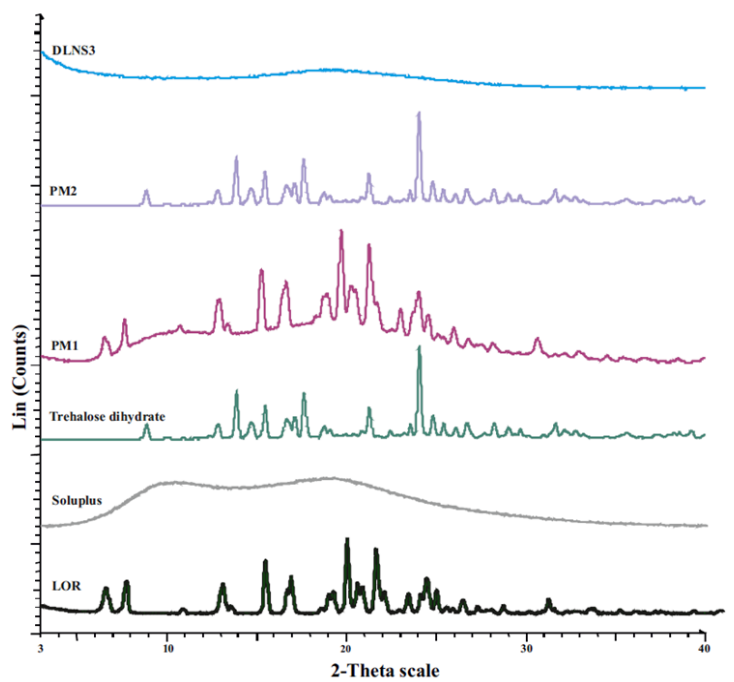

Figure 4.

XRPD diffractograms of LOR, Soluplus ${ }^{\circledR}$, PM1, PM2 and DLNS3

Surface free energy and polarity investigation Table VI lists the results of polarity and contact angles. Water contact angle decreased for PM1, and DLNS3 showed the lowest value, indicating the highest wetting properties. When diiodomethane was used instead of water, DLNS3 showed an increase to $23.1^{\circ}$ compared to approximately 13.5 of LOR and PM1. The increase in SFE suggests the conversion of the surface toward higher polarity. These results were confirmed by measuring the polarity \%, where DLNS3 showed the highest value $(33.65 \%)$. 
Contact angle, surface free energy and polarity of LOR, PMs and DLNS3

\begin{tabular}{ccccc}
\hline Sample & $\boldsymbol{\theta}$ water $\left({ }^{\circ}\right)$ & $\boldsymbol{\theta}$ diiodomethane $\left({ }^{\circ}\right)$ & $\gamma(\mathbf{m N} / \mathbf{m})$ & Polarity (\%) \\
\hline LOR & 75.7 & 13.5 & 52.3 & 9.4 \\
PM1 & 72.1 & 13.3 & 55.8 & 10.6 \\
PM2 & - & - & - & - \\
DLNS3 & 22.9 & 23.1 & 76.7 & 33.7 \\
\hline
\end{tabular}

(-) indicates unmeasurable data due to the instantaneous absorption of the drop

\section{Solubility and dissolution}

DLNS3 exhibited a marked increase in the solubility and dissolution of LOR (Table VII). It showed $59.39 \pm$ $5.18 \mu \mathrm{g} / \mathrm{mL}$ with 121 -fold enhanced solubility compared to LOR that showed a solubility of $0.49 \pm 0.001 \mu \mathrm{g} / \mathrm{mL}$. Two main factors are responsible for such enhancement; the reduction in particle size and the wettability of the polymers. The dissolution of nanoparticles is enhanced based on Noyes-Whitney equation [16]. Moreover, Soluplus ${ }^{\circledR}$ can create a hydrophilic environment around the drug nanoparticles. PMs showed higher solubility than LOR due to the wettability enhancement of Soluplus ${ }^{\circledR}$. However, trehalose slightly affects the solubility of LOR as the solubility of PM2 was comparable to that of PM1.

Figure 5 shows the dissolution profiles of the samples. LOR exhibited low drug release, less than $2 \%$ within the first $15 \mathrm{~min}$, and the maximum release was approximately $5 \%$ after $2 \mathrm{~h}$. PM1 and PM 2 showed a release of 4.7 and $7 \%$ after $2 \mathrm{~h}$, respectively. On the contrary, release from DLNS3 was high, approximately $57 \%$ in the first $15 \mathrm{~min}$ and $80 \%$ after $2 \mathrm{~h}$.

Table VII

LOR, PMs and DLNS3 solubility in PBS, $\mathrm{pH} 7.4$ at

$37^{\circ} \mathrm{C}$

\begin{tabular}{cc}
\hline Sample & Solubility $(\mu \mathrm{g} / \mathrm{ml})$ \\
\hline LOR & $0.49 \pm 0.001$ \\
PM1 & $10.35 \pm 3.75$ \\
PM2 & $11.46 \pm 2.82$ \\
DLNS3 & $59.39 \pm 5.18$ \\
\hline
\end{tabular}

Table VIII lists \%DE values for different time periods in addition to MDT and RD60. At $30 \mathrm{~min}$, the DE value of the drug is only $1.6 \%$ with a low value also for PMs, while DLNS3 showed a high release of $47.0 \%$. Similar increments were observed at 60 and 120 min with a maximum DE shown by DLNS3 at 120 min (67.3\%). Moreover, RD60 of DLNS3 showed an observed enhancement compared to PMs. On the other hand, MDT showed a maximum reduction with DLNS3 which emphasized the faster dissolution of the nanoscale formulation.

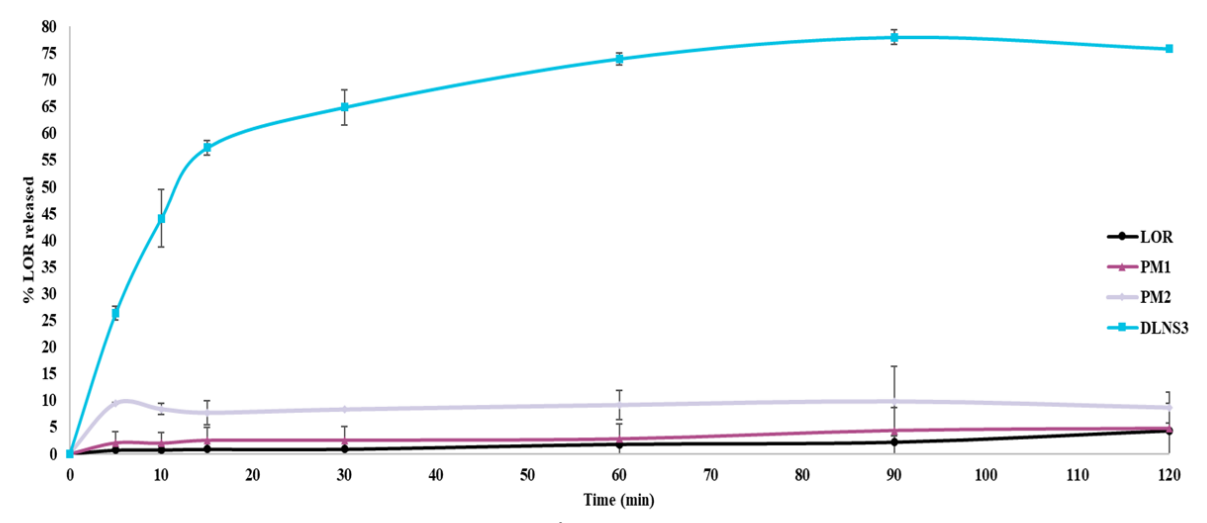

Figure 5.

Dissolution curves of LOR, PMs and DLNS3

Table VIII

$\% \mathrm{DE}, \mathrm{RD}$ and MDT values of PM and DLNS3

\begin{tabular}{cccccc}
\hline Sample & \%DE30 & \%DE 60 & \%DE 120 & MDT & RD 60 \\
\hline LOR & 1.6 & 1.5 & 2.0 & 34.3 & - \\
PM1 & 2.1 & 2.4 & 3.2 & 32.0 & 1.6 \\
PM2 & 7.6 & 8.1 & 8.7 & 16.0 & 5.4 \\
DLNS3 & 47.0 & 58.2 & 67.3 & 11.2 & 38.3 \\
\hline
\end{tabular}

\section{Conclusions}

QbD showed an efficient tool for predicting the product's quality. The use of risk analysis for selecting high-risk factors and the further evaluation of those factors save time and costs by providing the visual identification of high-risk factors. The high impact relationships between CMPs, CPPs and CQAs that were suggested by the $\mathrm{QbD}$ based approach were 
FARMACIA, 2019, Vol. 67, 4

proved by studying the effects of changing the stabilizer type. Compared to the previously used stabilizers (e.g. HPMC, PVP-K25, F68, Tween 80 and SLS), Soluplus ${ }^{\circledR}$ showed an expected difference in particle size, particle size distribution, zeta potential, morphology, dissolution and solubility with preferred effects related to lower particle size, higher zeta potential, thus stability, higher dissolution rate and immense solubility enhancement.

\section{Conflict of interest}

The authors report no conflicts of interest related to this work.

\section{Acknowledgement}

Ministry of Human Capacities, Hungary grant 203913/2018/FEKUSTRAT is acknowledged.

\section{References}

1. Müller RH, Peters K, Nanosuspensions for the formulation of poorly soluble drugs. I. Preparation by a size-reduction technique. Int J Pharm., 1998; 160(2): 229-237.

2. Patravale VB, Date A, Kulkarni RM, Nanosuspensions: a promising drug delivery strategy. $J$ Pharm Pharmacol., 2004; 56(7): 827-840.

3. Ambrus R, Kocbek P, Kristl J, Šibanc R, Rajkó R, Szabó-Révész $\mathrm{P}$, Investigation of preparation parameters to improve the dissolution of poorly water-soluble meloxicam. Int J Pharm., 2009; 381(2): 153-159.

4. Bartos C, Kukovecz Á, Ambrus R, Farkas G, Radacsi N, Szabó-Révész P, Comparison of static and dynamic sonication as process intensification for particle size reduction using a factorial design. Chem Eng Process Process Intensif., 2015; 87: 26-34.

5. Anil P, Pravin C, Prashant G, Amol P, Prakash B, Study the Effect of Surfactant Concentration and Ultrasonication Time on Aqueous Solubility, Particle Size and In-vitro Drug Diffusion of Ezogabine Nanosuspension by 32 Factorial Designs. Br Biomed Bull., 2016; 4(1): 15-26.

6. Kumar S, Gokhale R, Burgess DJ, Quality by Design approach to spray drying processing of crystalline nanosuspensions. Int $J$ Pharm., 2014; 464(1-2): 234-242.
7. Dagenais C, Avdeef A, Tsinman O, Dudley A, Beliveau $\mathrm{R}$, P-glycoprotein deficient mouse in situ bloodbrain barrier permeability and its prediction using an in combo PAMPA model. Eur J Pharm Sci., 2009; 38(2): 121-137.

8. Frizon F, Eloy J de O, Donaduzzi CM, Mitsui ML, Marchetti JM, Dissolution rate enhancement of loratadine in polyvinylpyrrolidone K-30 solid dispersions by solvent methods. Powder Technol., 2013; 235: 532-539.

9. Nacsa Á, Ambrus R, Berkesi O, Szabó-Révész P, Aigner Z, Water-soluble loratadine inclusion complex: Analytical control of the preparation by microwave irradiation. J Pharm Biomed Anal., 2008; 48(3): 1020-1023.

10. Nacsa Á, Berkesi O, Szabó-Révész P, Aigner Z, Achievement of $\mathrm{pH}$-independence of poorly-soluble, ionizable loratadine by inclusion complex formation with dimethyl-ß-cyclodextrin. J Incl Phenom Macrocycl Chem., 2009; 64(3-4): 249-254.

11. Li H, Tan Y, Yang L, Gao L, Wang T, Yang X, Dissolution evaluation in vitro and bioavailability in vivo of self-microemulsifying drug delivery systems for $\mathrm{pH}$-sensitive drug loratadine. J Microencapsul., 2015; 32(2): 175-180.

12. Vlaia L, Coneac G, Olariu I, Muţ AM, Anghel DF, Maxim ME, Saramet G, Mitu M, Lupuliasa D, Vlaia. $\mathrm{V}$, Loratadine-loaded microemulsions for topical application. Formulation, physicochemical characterization and in vitro drug release evaluation. Farmacia. 2017; 65(6): 851-861.

13. Tefas LR, Rus LM, Achim M, Vlase L, Țomuță I. Application of the quality by design concept in the development of quercetin-loaded polymeric nanoparticles. Farmacia, 2018; 66(5): 798-810.

14. Pallagi E, Ambrus R, Szabó-Révész P, Csóka I, Adaptation of the quality by design concept in early pharmaceutical development of an intranasal nanosized formulation. Int J Pharm., 2015; 491(1-2): 384-392.

15. Alshweiat A, Katona G, Csóka I, Ambrus R, Design and characterization of loratadine nanosuspension prepared by ultrasonic-assisted precipitation. Eur $J$ Pharm Sci., 2018; 122: 94-104.

16. Yang $\mathrm{H}$, Teng $\mathrm{F}$, Wang $\mathrm{P}$, Tian $\mathrm{B}$, Lin $\mathrm{X}, \mathrm{Hu} \mathrm{X}$, Investigation of a nanosuspension stabilized by Soluplus ${ }^{\circledR}$ to improve bioavailability. Int J Pharm., 2014; 477(1-2): 88-95. 